\title{
THE HARVARD'S BRAIN DEATH CRITERIA AS A BASIS FOR THE WITHDRAWAL OF LIFE SUPPORT MACHINES: A RESPONSE FROM ISLAMIC LAW
}

\author{
Bashir Ompidian *
}

\begin{abstract}
Patients in coma or vegetative state are usually dependent on life support machines or system, until they either recover or pass away. However, the story is no longer the same today, as patients are in a coma or vegetative state are sometimes disconnected from such machines, in order to save cost. Apart from disconnecting them from the machine, they are equally denied food and drink, being basic necessities of life. This is resorted to in order to quicken the pace of death. Health officials have always relied on the Harvard's brain death criteria as the basis for their actions. Research has however shown that the said brain death criterion is not reliable after all. Thus, this article examines the justifiability of the brain death criteria as the basis for the withdrawal of life support machines. In doing so, the article provides the Islamic view point on the issue. It will at the end, show that, indeed the brain death criterion is faulty and should never be the basis for the withdrawal of a patient's life support machine, denied food and drink and denial of medical treatment.
\end{abstract}

Keywords: response of Islamic law, Harvard brain death criteria, withdrawal of life support machines, denial of medical treatment

Associate Professor (READER), Department Of Private \& Property Law, Faculty of Law, University Of Ilorin, Ilorin, Kwara State, Nigeria. 


\title{
PANDANGAN ISLAM TERHADAP KRITERIA PENENTUAN KEMATIAN HARVARD SEBAGAI PENYEBAB PENARIKAN ALAT BANTUAN PERNAFASAN
}

\begin{abstract}
ABSTRAK
Pesakit dalam keadaan koma atau tidak sedar diri selalunya diberi makan melalui alat atau sistem tertentu. Disamping itu mereka juga bergantung kepada alat bantuan pernafasan untuk terus hidup. Keadaan ini akan berterusan sehingga mereka sembuh atau meninggal dunia. Walaubagaimanapun, keadaan ini sudah berubah sekarang dimana pesakit yang mengalami koma ada kalanya dihentikan dari menggunakan alat bantuan pernafasan bagi menyelamatkan kos. Di samping itu, mereka juga tidak di berikan makanan dan minuman bagi mempercepatkan proses kematian. Keadaan ini terjadi apabila pihak hospital terutamanya para doktor kini yang menetapkan kematian berdasarkan kriteria penentuan kematian Harvard bagi menentukan samada pesakit hidup atau mati. Kajian lampau menunjukkan bahawa kriteria penentuan kematian tersebut tidak lagi boleh diguna pakai. Oleh sebab itu, makalah ini melihat samada kriteria ini masih sesuai digunakan sebagai sebab untuk menarik alat bantuan pernafasan dari seseorang pesakit. Makalah ini juga akan menggariskan pendapat Islam terhadap isu penting ini. Akhirnya, makalah ini akan menunjukkan bahawa kriteria penentuan kematian Harvard adalah salah dan tidak lagi boleh digunakan sebagai asas untuk menarik balik alat bantuan pernafasan serta menghentikan bantuan perubatan terhadap pesakit.
\end{abstract}

Kata Kunci: pandangan Islam terhadap kriteria penetuan kematian Harvard, penarikan balik alat bantuan pernafasan, penghentian bantuan perubatan 


\section{INTRODUCTION}

The Harvard brain death criteria emanated from Harvard's School of Medicine in $1968 .^{1}$ Since then, it has become the basis for the removal of a patient's life support, when such patient is either in coma or permanent vegetative state. According to advocates in support of this view, when a person is in a permanent vegetative state, to continue to keep him or her on a life support machine, amounts to waste of scarce resources. ${ }^{2}$ Recent researches have however shown that, the said criterion should never be the basis for the withdrawal of a patient's treatment, because of the loopholes inherent in it. ${ }^{3}$ It has also been argued further that persons in coma have had their life support withdrawn mainly to boost organ transplantation and to save tax payers' money. ${ }^{4}$ Thus, advocates against the view opined that if patience is resorted to, these patients may still regain consciousness, a fact which recent researches have proved. ${ }^{5}$ Hence, they concluded

1 "A Definition of Irreversible Coma: Report of the Ad Hoc Committee of the Harvard Medical School to Examine the Definition of Brain Death," Journal of American Medical Association 205, no. 6 (1968): 337-40, http://dx.doi.org/10.1001/jama.1968.03140320031009.

2 Martin Beckford, "Baroness Warnock: Dementia Sufferers May Have a 'Duty to Die,"” accessed April 19, 2016, http://www.telegraph.co.uk/news/uknews/ 2983652/Baroness-Warnock-Dementia-sufferers-may-have-a-duty-to-die.html; Hilary White, "British 'Moralist' Says Dementia Patients Have a 'Duty to Die' Europe - International - News - Catholic Online," Catholic Online, September 23, 2008, http://www.catholic.org/news/international/europe/story.php? id $=29538$.

3 Martin M Monti et al., "Willful Modulation of Brain Activity in Disorders of Consciousness," New England Journal of Medicine 362, no. 7 (2010): 579-89; Martin M Monti, Martin R Coleman, and Adrian M Owen, "Neuroimaging and the Vegetative State," Annals of the New York Academy of Sciences 1157, no. 1 (2009): 81-89; Steven Laureys, Adrian M Owen, and Nicholas D Schiff, "Brain Function in Coma, Vegetative State, and Related Disorders," The Lancet Neurology 3, no. 9 (2004): 537-46; Adrian M Owen and Martin R Coleman, "Functional Neuroimaging of the Vegetative State," Nature Reviews Neuroscience 9, no. 3 (2008): 235-43.

4 Monti et al., "Willful Modulation of Brain Activity in Disorders of Consciousness"; Owen and Coleman, "Functional Neuroimaging of the Vegetative State"; Laureys, Owen, and Schiff, "Brain Function in Coma, Vegetative State, and Related Disorders"; Monti, Coleman, and Owen, "Neuroimaging and the Vegetative State."

5 Roger N Rosenberg, "Consciousness, Coma, and Brain death-2009," Journal of American Medical Association 301, no. 11 (2009): 1172-74; Robert J Joynt, 
that a patient's life support should only be withdrawn if further treatment will not only be futile, but the sustenance of the patient does not depend on the machine. This is where Islamic law takes centre stage, because a person is not allowed to kill another, without just cause, except if the same was done by mistake. ${ }^{6}$ Thus, this paper examines the brain criteria, its criticisms and the response of Islamic law to it.

\section{THE BRAIN DEATH CRITERIA: DEFINITION}

According to the Ad-Hoc Committee of the Harvard Medical School, brain death has been defined as a situation whereby there is an irreversible coma, such that the brain stops functioning. This is as a result of the absence of blood circulation to the brain which ultimately causes brain necrosis. ${ }^{7}$ The above definition came into being in 1968 , and since then, it has been the basis for determining the death of a person. $^{8}$ The above definition is supported by the National Kidney Foundation in 2015 when it states, brain death is a legal definition of death. It is the complete and irreversible cessation (stopping) of all brain function. ${ }^{9}$ It means that, as a result of severe trauma or injury to the brain, the body's blood supply to the brain is blocked, and the brain dies. When a person is diagnosed as suffering from brain death, he is considered to have died. It is permanent and irreversible. In the same vein, the Encyclopaedia Free Dictionary states that the brain of an individual with brain death must have ceased to function. It stated further that, such person must make no response to pain and no cranial nerve reflexes ${ }^{10}$ upon examination. ${ }^{11}$ Such reflexes, according

"Landmark Perspective: A New Look at Death," Journal of American Medical Association 252 (1984): 68-682.

6 Abdullah Yusuf Ali, The Holy Qur'an: Text Translation \& Commentary (1984, U.S.A) see also The Qur'an (al- Isrā': 33); Al-Bukhari, Muhammad b. Ismail. (1981). Sahih al-Bukhari. (Istanbul: Al-Maktabah al Islamiyyah, 1981) vol. iviii.

7 "A Definition of Irreversible Coma: Report of the Ad Hoc Committee of the Harvard Medical School to Examine the Definition of Brain Death."

8 Ibid.

9 "Brain Death - The National Kidney Foundation," accessed April 19, 2016, https://www.kidney.org/atoz/content/braindeath.

10 The corneal is one of the blink reflexes, is an involuntary blinking of the eyelids elicited by stimulation of the cornea. Stimulation should elicit both a direct and indirect or consensual response (opposite eye). The reflex consumes a rapid rate 
to the dictionary, include papillary response (fixed pupils), Oculocephalic reflex, ${ }^{12}$ and corneal reflex ${ }^{13}$ and there should be no response to the Caloric reflex test ${ }^{14}$ and respirations. ${ }^{15}$

\section{THE CRITERIA AGAINST THE BRAIN DEATH CRITERIA}

However, in all the situations explained above, part of a patient's brain with severe irreversible neurological dysfunction can still work or function. This function will include quick response to respiration, notwithstanding the patient's loss of both cortex and brain stream. ${ }^{16}$ Thus, it is concluded that anencephaly, ${ }^{17}$ which transform into the lack of higher brain is never a brain death. ${ }^{18}$ This is because, although it is an irreversible condition, which may necessitate the withdrawal of life support, research has however shown that patients in such state

of 0.1 second. The evolutionary purpose of this reflex is to protect the eyes from foreign bodies. "Teach Neurology: The Corneal or Blink Reflex," accessed April 19, 2016, http://teachneuro.blogspot.my/2013/01/the-corneal-or-blinkreflex.html.

11 "Brain Death | Encyclopedia Article by TheFreeDictionary," accessed April 19, 2016, http://encyclopedia.thefreedictionary.com/brain+death.

12 Oculocephalic and oculvestibular reflexes are primarily used to determine whether a patient's brainstem is intact (e.g. coma or brain death assessment), "Oculocephalic and Oculovestibular Reflexes," accessed April 19, 2016, http://lifeinthefastlane.com/ccc/oculocephalic-and-oculovestibular-reflexes/.

13 Corneal reflex is a contraction of eyelids when cornea is lightly touched with any soft material (camel's hair pencil); it equally occurs when light reflected from the surface of the cornea, "Corneal Reflex -- Medical Definition," accessed April 19, 2016, http://www.medilexicon.com/medicaldictionary.php?t=76722.

14 Caloric stimulation is a test that uses differences in temperature to diagnose damage to the acoustic nerve. This is the nerve that is involved in hearing and balance. The test also checks for damage to the brain stem. "Caloric Stimulation: MedlinePlus Medical Encyclopedia," accessed April 19, 2016, https://www.nlm.nih.gov/medlineplus/ency/article/003429.htm.

15 The statement above, i.e. no response to caloric reflex test and respirations means that there must be total cessation of all functional organs of the body. Ibid.

17 Anencephaly is a serious birth defect in which a baby is born without parts of the brain and skull. It is a tyoe of neural tube defects (NTD). As the neural tube forms and closes, it helps from the baby's brain and skull (upper part of the neural tube), spinal cord, and back bones (lower part of the neural tube). "Facts about Anencephaly | Birth Defects | NCBDDD | CDC," accessed April 19, 2016, http://www.cdc.gov/ncbddd/birthdefects/anencephaly.html.

Ibid. 
still recover. ${ }^{19}$ Hence, when properly examined, the above definition attests to the fact that the brain death criterion is beset with some uncertainties. One major uncertainty was revealed by the definition put forward by the American Heritage Dictionary. Apart from revealing the uncertain nature of the Harvard criteria, it equally showed that if a patient's life support machine is withdrawn on the basis of the brain death criteria, such an act would amount to murder. According to the dictionary, brain death means, "permanent brain damage which results in loss of brain function." 20 This loss of brain function, according to this definition, is shown by the cessation of breathing and other vital reflexes, ${ }^{21}$ which also includes unconsciousness with unresponsiveness to stimuli, absence of muscle activity, and a flat electroencephalogram for a predetermined length of time. ${ }^{22}$ Thus, it concluded that patients who are brain dead may still exhibit normal function of the heart, lungs, and other vital organs, provided they are on artificial life support system. On the basis of the above statement, one may want to consider opinions of those opposed to the Harvard's brain death criteria. This is because the criterion signifies the hastening of the death of a human being, when such being is still alive. Research has also shown that some persons still hold the criteria in high esteem, because it is a boost for organ transplantation. Apart from this, it has also afforded some governments the opportunity of running away from spending heavily on the health of their citizens. This is so because, with the criteria, the provision of life support machines would no longer be necessary, in order to save cost.

It is in the light of the above that stake holders have recently frowned at the definition of death, on the basis of a reliance on the Harvard's brain death criteria. ${ }^{23}$ According to medical scientists, the absence of discernable brain function which is the hall mark of the criteria has been said to be different from brain necrosis or true brain

\footnotetext{
Ibid.

"Brain Death | Encyclopedia Article by TheFreeDictionary."

Ibid.

Ibid.

Celso Galli Coimbra, "Doctor to Tell Brain Death Conference Removing Organs from 'Brain Dead' Patients Tantamount to Murder," accessed April 19, 2016, https://biodireitomedicina.wordpress.com/2009/02/18/doctor-to-tell-brain-deathconference-removing-organs-from-brain-dead-patients-tantamount-to-murder/.
} 
death. ${ }^{24}$ This is because even in patients that discernable brain function has been found to be absent, they nonetheless have survived, when adequate treatments are provided. Thus, to these experts, reliance on the Harvard brain death criteria would only result in the removal of organs from living patients, because as at the said time of removal the basis of the removal (which is that the patient is dead) wouldn't have met the actual death criteria, which is total cessation of all bodily functional organs. ${ }^{25}$

According to one of these experts, Paul Byrne, total cessation of brain activity or irreversible coma, as the Harvard report puts it, should mean the stoppage of the heartbeat. ${ }^{26}$ He stated further that this criterion is the reason why proponents of euthanasia have classified patients who are in irreversible coma as dead, in order to allow such patients to be dehydrated to death. ${ }^{27}$ Dehydration of patients to death is usually carried out by the removal of patients' feeding tube, coupled with the denial of food and drink. It is important to note here that the removal of the feeding tubes of Terri Schiavo of the United States of America and Eluana Englaro of Italy in 2005 and 2009 respectively, attests to the fact that, withdrawal of feeding tubes from patients whose means of sustenance are dependent on same, amounts

Ibid.

25 Paul A. Byrne, "The Demise of 'Brain Death,"” accessed April 19, 2016, http://www.renewamerica.com/columns/byrne/080908. Dr. Paul A. Byrne is a Board Certified Neonatologist and Paediatrician. He is the Founder of the Neonatal Intensive Care Unit at SSM Cardinal Glennon Children's Medical Center in St. Louis, MO. He is Clinical Professor of Paediatrics at University of Toledo, College of Medicine. He is a member of the American Academy of Paediatrics and Fellowship of Catholic Scholars. Dr. Byrne is past-President of the Catholic Medical Association (USA), formerly Clinical Professor of Paediatrics at St. Louis University in St. Louis, MO and Creighton University in Omaha, NE. He was Professor of Paediatrics and Chairman of the Paediatric Department at Oral Roberts University School of Medicine and Chairman of the Ethics Committee of the City of Faith Medical and Research Center in Tulsa, OK. He is author and producer of the film "Continuum of Life" and author of the books "Life, Life Support and Death," Ibid.

27 Ibid. 
to murder. ${ }^{28}$ Similarly, Cicero Coimbra a neurologist, in his own opposition against the brain death criteria, said at the Conference on Brain Death held between the $19^{\text {th }}$ and $20^{\text {th }}$ day of February, 2009 in Rome, that it is the same apnoea test that are applied to patients suffering from brain injury which in turn causes "brain necrosis; or permanent and irrecoverable brain damage". ${ }^{29}$ The scholar stated further that, "applying the apnoea "brain death" method produces the opposite of recuperative treatment, thereby quickening the pace of brain damage." " According to him, "tests needed to establish "brain death" require a normal body temperature", which, in his opinion, "necessitates the removal of ventilator support." This removal, the scholar added, will in turn result in an increase of the carbon dioxide level in the blood." 31 This, according to the erudite scholar, is what

28 Eluana, is referred to as Terri Schiavo because the latter's case is similar to her own. For instance, Terry Schiavo was on a feeding tube after an auto accident. Her husband therefore sought to remove same, so she can die. This action did not go down well with the parent of Schiavo, leading to series of legal battle between the duos. At the end of it all, the United States of America's Supreme Court confirmed the decision of both the lower court and the court of appeal. Consequently, Terri was dehydrated to death. In Eluana's case, the father wanted the feeding tube removed and the Italian government decided to move swiftly against the decision of the lower court to that effect. However, both the court of appeal and the Italian Supreme court, upheld the lower court's decision. The Italian parliament, not wanting to give up, began a process of promulgating a law that will make dehydration of patients on life support illegal, however, the refusal of the president to sign a temporary measure, which would have saved Eluana, encumbered the process. Eventually, Eluana, like Terri, was dehydrated to death. The cause of the death of these two ladies can be attributed to the lack of adequate legislation on euthanasia and assisted suicide issues by both the United States of America and Italy. For explanations on the dehydration to death of Terri Schiavo and Eluana Englaro, see also "Italian Coma Row Patient Dies," accessed April 19, 2016, http://www.aljazeera.com/news/europe/2009/ 02/20092919501173999.html.;Greer, George W, Circuit Judge. "In Re: The Guardianship of Theresa Marie Schiavo, Incapacitated. Michael Schiavo V. Robert Schindler\& Mary Schindler, File No. 90-2908-GD-003, Fla. $6^{\text {th }}$ Judicial Circuit.

29 Cícero Galli Coimbra, "Implications of Ischemic Penumbra for the Diagnosis of Brain Death," Brazilian Journal of Medical and Biological Research 32, no. 12 (1999): 1479-87.

30 Ibid.

31 Cícero Galli Coimbra, "Apnoea Brain Death Test May Kill The Patient," accessed April 19, 2016, http://www.geocities.ws/newcannibals/ Ch3ApnoeaBrainDeath.html. 
advocates of the Harvard brain death criteria, call brain death. ${ }^{32} \mathrm{He}$ equally pointed out that, since the criteria came into being in 1968, many patients have been killed erroneously across the whole world. ${ }^{33}$

At the same conference, another expert, Seifert Josef, called for an outright rejection of the Harvard criteria because, "it provides absolutely no theoretical or scientific value to determine death." 34 All the clinical neurologists and cardiologists at the conference were in agreement with the learned professor and concluded that a patient who is declared "brain dead" by the stated criteria is still alive. ${ }^{35}$ It is instructive to state here that all the above positions are amply supported by the 1975 National Institute of Health study on brain death. ${ }^{36}$ According to the outcome of the study, of the 228 comatose patients that are said to be brain dead, for at least 48 hours, only $50 \%$ of them have pathological signs of necrosis. ${ }^{37} 21 \%$ of the patients have no sign of dead brain cells. ${ }^{38}$ The reports stated further that even patients that have no signs of synaptic activity, a condition of the brain death diagnosis, can still recover at that point. The 2010 study equally lend credence to this fact. ${ }^{39}$

32 Ibid. Note that Apnoea test is also a term used for the suspension of external breathing. It states further that when apnoea test is on, the muscle of respiration will be motionless and the volume of the lungs too will not change. Furthermore, unless ventilation is restored, apnoea test may cause permanent brain damage within three minutes. Consequently, death will ensue in another few minutes after the brain damage.

33 Cícero Galli Coimbra, "Evidence-Based versus 'Established' Medical Practice," British Medical Journal 325 (2002): 836.

34 “Hilary White, “'Brain Death' Is Life, Not Death: Neurologists, Philosophers, Neonatologists, Jurists, and Bioethici | News | LifeSite," accessed April 19, 2016, https://www.lifesitenews.com/news/brain-death-is-life-not-deathneurologists-philosophers-neonatologists-juri.

Ibid.

36 "Brain Death - The National Kidney Foundation."

37 "Brain Death is Never Really Death," accessed April 19, 2016, http://www.lifesitenews.com/idn/2008/mar/08032709.html.

38 Ibid.

39 Monti et al., "Willful Modulation of Brain Activity in Disorders of Consciousness." 


\section{CASES IN SUPPORT OF THE CRITICISM AGAINST THE BRAIN DEATH CRITERIA}

\section{Decided Cases}

\section{In The Matter Of Quinlan ${ }^{40}$}

In this case, Karen Quinlan, a 21 year old lady, was in comma and stopped breathing in 1975. Lots of effort was made to resuscitate her through the mouth to mouth process but due to lack of oxygen she suffered serious brain damage. Consequently, she became vegetative. She was therefore put under the life support machine wherein she could receive nutrition and hydration. Upon being informed by the hospital authorities that she could never regain consciousness again, Karen's parent asked that the respirator be removed so that she could die. This request was rebuffed by the hospital authority on the basis that according to medical and legal standard she is not dead yet. In other words, cognitive functioning must have stopped completely before death can be said to have occurred.

\section{Decision by the Court}

At the lower court, it was held that the contentions of Karen's parent that their daughter has a constitutionally protected right to die is not known to American law, therefore the request for guardianship failed. The matter went to the New Jersey's Supreme Court and the Supreme Court over ruled the lower court and granted Karen's father the right to be the legal guardian of his daughter. This also includes making decisions regarding her treatment.

The basis for the decision in this case, is the request of the Quinlans was only granted on the ground that their right to privacy conferred on them the privilege of taking decisions regarding the treatment of their daughter. Delivering its judgment, the court held amongst others that,

[W]e have no hesitancy in deciding....that no external compelling interest of the state could compel Karen to endure the unendurable; only to vegetate a few measurable months with no realistic

$40 \quad$ Re Quinlan (1976) 429 US 922; see also "Karen Ann Quinlan (in the Matter of Quinlan 1975)," accessed April 19, 2016, http://www.deathreference.com/menu/naturaldeath-acts.html. 
possibility of returning to any semblance of cognitive or sapient life." $" 41$

The court adds, "the state interest weakens and the individual right to privacy grows as the degree of bodily invasion increases and the progress dims." It states further that, "ultimately there comes a point at which the individual's right overcome the state interest." 42 The court, while specifically refuting the Attorney General's contention that any action that hastens death of another individual constitutes criminal homicide, concludes by saying that,

[W] conclude that there would be no criminal homicide in the circumstance of this case. "We believe that the ensuing death would not be homicide but rather expiration from existing natural causes." Secondly, "even if it were to be regarded as homicide, it would not be unlawful....

The learned jurists proceeded by differentiating between killing and letting to die, when they said that, "there is a real distinction between the unlawful taking of the life of another and the ending of artificial life support system as a matter of self-determination."

In analysing this celebrated case the following must be noted, that the New Jersey's Supreme Court did not base its decision on the right to die, but on the basis of the fact that there exist a legal right to selfdetermination to refuse medical treatment, even if the resultant effect is death. Further, this case equally established the principle, that where the patient is incapacitated as a result of being in a vegetative state, their parent or family members have the legal competence to decide what become of their treatment.

Finally, the case establishes the principle distinguishing the refusal of treatment in which the resultant effect is death and the more active method of hastening death.

The judgment as it concern this paper shows that the parent in asking that the life support machine of Karen be withdrawn based their argument on the Harvard's brain death criteria, which has been opposed severally in this work. Similarly, the hospital, in spite of telling Karen's parent that she will never regain consciousness, refused to accede to the request for removal of life support because

\footnotetext{
$41 \quad$ Ibid, 663.

42 Ibid, 664.

43 Ibid, 669-670.
} 
the patient (Karen) can still be fed with water and food (Nutrition and hydration). This latter position of the hospital authorities is in tandem with the position of this paper that a brain death patient is not dead until there is total cessation of all functional bodily organs and not when the brain stops functioning as Harvard's brain death criteria states.

The position of this paper is further supported by the fact that Karen did not die after the removal of the life support machine until after another eight years. This case can therefore be said to reveal certain facts about removal of life support. In the first place, the hospital authorities, who refuse to remove the life support, because Karen has not yet died according to accepted medical and legal condition, may have acted rightly. This is so considering the fact that she died eight years after the removal of the life support. ${ }^{44}$ It will therefore be safe to conclude that the removal of Karen's life support is in line with the Harvard brain death criterion which is what this present paper is opposed to. ${ }^{45}$

\section{Re Terri Schiavo ${ }^{46}$}

This case, which is the latest of cases decided by the United States judiciary, followed the laid down principle of withdrawal of treatment as decided in the earlier case cited. Terri Schiavo, a Floridian who has been in a vegetative state since 1990, had to be dehydrated to death. There were disagreement between Schiavo's husband and her family. The then American President, George Bush also made spirited effort at ensuring that her feeding tube was not removed, but all to no

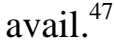

However, the court finally gave the husband the right to do so. Consequently, the feeding tube of Theresa Marie Schiavo was removed, culminating in her eventual death on the $31^{\text {st }}$ day of March, 2005 , fifteen years after she had become vegetative. The crux of the argument then was that the husband claimed he had the mandate of

\footnotetext{
$44 \quad$ Re Quinlan

45 This is so because, as at the time, the feeding tube was on, Karen was still alive. It therefore means that her sustenance depended on the life support machine. The subsequent removal, and the eventual death that ensued, can therefore be likened to active intervention in killing, which amounts active euthanasia.

46 Greer, George W, Circuit Judge. "In Re: The Guardianship of Theresa Marie Schiavo, Incapacitated. Michael Schiavo V. Robert Schindler\& Mary Schindler, File No. 90-2908-GD-003, Fla. $6^{\text {th }}$ Judicial Circuit, 25 February, 2005. Ibid.
} 
his wife to remove the feeding tube. But the absence of a previous living will to confirm it, and the fact that the rest of the family members of Schiavo were not in agreement with the position of the husband necessitated the court action.

\section{Decision by the Court}

The Pinellas county circuit court of Florida, while finding for the petitioner, held that on the basis of the credible and reliable statement of the expert witness, the feeding tube of Theresa Marie Schiavo should be removed. ${ }^{48}$

Thus, the court placed reliance on the previous advance directive which Terri's husband, told the court, had orally been made by his wife before becoming vegetative. According to Michael, Terri's husband, the latter had earlier expressed her wish not to be kept alive under a machine with no hope of improvement. ${ }^{49}$ Dissatisfied with the above decision, the respondents who are Terri's parent embarked on series of appeal to see that Terri's feeding tube was reinserted. ${ }^{50}$ Although, they won in some instances, the case witnessed a total of fourteen appeals and series of petitions at the Florida court. ${ }^{51}$ The struggle finally came to an end with the refusal of the United States Supreme Court to grant Terri's parent, an order of certiorari on the $21^{\text {st }}$ day of March, 2005. ${ }^{52}$

48 The expert witness referred to by the court, include Terri's husband and her sister in-law (Michael's sister). With respect to the Pinellas court, can these persons, under the law of evidence be regarded as experts? The answer seems to be in the negative. This is so because the husband wanted to get himself off the hook, and who else will the other witness lean towards, if not Terri's husband, who happens to be her own blood.

"IN RE: GUARDIANSHIP OF Theresa Marie SCHIAVO | FindLaw," accessed April 20, 2016, http://caselaw.findlaw.com/fl-district-court-ofappeal/1391046.html.,

50 Ibid.

51 Appeals in the above case were much because of the uncertain nature of the United States law on withdrawal or withholding of treatment. Thus, different verdicts, premised on different principles were delivered by different court. These courts include the court of first instance, which is the Pinellas court, the Federal court in Florida, the Federal appeals court, also in Florida, and the United States Supreme Court respectively. For instance see Dept of Children and Family Services v Micheal Schiavo In Re: Theresa M. Schiavo, 2D05-1300 L.T No: 90-2908GD-003, [16 March, 2005].

52 See Schiavo, EX REL. SCHINLDER v Schiavo Michael, Et Al, Order List 544 US -04A825. The above case represents the last straw that breaks the camel's 
The above decision is a confirmation of the fact that a law must be specific and not ambiguous, as the United States law on euthanasia and assisted suicide is. For instance in Quinlan and Cruzan's case, the United States Supreme Court laid down the principle that there exist a right to terminate life sustaining interventions for terminally ill persons. ${ }^{53}$ But throughout the duration of the medical examinations carried out on Terri, she was never confirmed to be terminally ill, and that had been the consistent arguments of her parent. More worrisome is the fact that witnesses who testified in support of the purported wishes of Terri are Michael, his brother and sister- in-law. ${ }^{54}$ It is therefore submitted that there was no basis for the approval to remove, and the affirmation by the Supreme Court of, Terri's feeding tube. This case, by the argument of Terri's parents, further proves that a brain dead person is not dead until all bodily functional organs ceases to function. This is because Terri's parents were of the view that she (Terri) will recover from the illness with time.

A careful perusal of the above decision reveals that Michael, Terri's husband seeks the removal of her wife's life support, not because she was brain dead, but because, according to him, her wife had earlier told him she does not want to be under a life support machine without any hope of recovery. With respect, if Terri ever mentioned that she does not want to be on a life support, it means the Harvard brain death criteria has been erroneously relied upon. It is important to stress here that medical examination did not even reveal Terri was terminally ill, and that is the argument of the parent in opposing the withdrawal of her life support device. This fact is further strengthened by the opposition of this paper to the brain death criteria as the basis for withdrawal of life support machine from patient because a brain dead person is not dead unless all functional bodily organs have ceased to work.

back. This is so because the refusal of the United States Supreme Court, to grant Terri's parents, the right of certiorari, set the final stage for the death of Terri.

53 Re Quinlan, n. 40; see also See Cruzan v Director, Missouri Dept. of Health [1990] U.S. 261, 110 S. Ct. 2841.

54 Theresa Marie Schindler Schiavo, Et Al v Micheal Schiavo, Et Al, DC Docket No. 05-00530-CV-T-27-TBM, [25 March, 2005]. 


\section{Cases that did not get to Court}

Apart from only one that got to court, all other cases to be examined under this heading did not get to court. They are interviews and statements credited to those who survived after being labelled as brain dead. Thus, those who have likened the brain death criteria to killing a human being relied on cases where patients, who had earlier been confirmed brain dead, have in fact survived. For instance, in Florida, one Mar Jorie Nighbert, could not swallow anything due to the stroke she suffered in January, $2007 .{ }^{55}$ As a result of this, she was being fed through a feeding tube. ${ }^{56}$ Prior to this period, she had made a 'living Will' in 1992, wherein she stated that her brother should take decisions on her behalf, in case she becomes incapacitated in taking a decision about her health in future. ${ }^{57}$ On the strength of the directive, the brother sought for the removal of her feeding tube. ${ }^{58}$ She later became hungry as a result of this removal and requested for food several times. Thus, when death became imminent as a result of the hunger, the matter was taken to court through a Right to Life group which contacted the Florida health and rehabilitation services.

Delivering its ruling, the court held that Mar Jorie was incompetent to ask for food because of her earlier 'living Will. ${ }^{59}$ The 'living Will,' according to the court, stated that she will not want to remain alive on a life support machine and later died on the $16^{\text {th }}$ day of April, 1995, as a result of her dehydration. ${ }^{60}$

In the words of the court, Circuit Court Judge Jere Tolton appointed attorney William F. Stone to represent Marjorie and gave

55 "I Judge You Unworthy of Life - Euthanasia," accessed April 20, 2016, http://www.euthanasia.com/elderly.html.

56 The above shows that once a patient's sustenance depends on life support, it should never be removed. To do so will be tantamount to initiating such patient's death.

57 The above affirms the danger in a 'living will,' coupled with the kind of person that is appointed as one's surrogate. If a person who is desperate to benefit from one's estate is made a surrogate, like the one in the above case, he or she will quicken the pace of removal of one's life support. Ibid.

59 The scenario above is only an affirmation of the fact that advanced directive, in form of a living will amounts to euthanasia by the back door. The reason being that once made, as shown by the court above, same can never be reversed, even if the maker, desire such reversal.

60 Ibid; see also Guardianship of Jane Doe, 411 Mass. 512, 583 N.E.2d 1263 (1992); In re Lawrance, 579 N.E.2d 32 (Ind. 1991). 
him twenty-four hours to determine whether she was competent to rescind the general power of attorney she had given to Maynard before her stroke. After the rushed investigation, Stone was forced to report that Marjorie was not competent at that time. (She had, after all, been intentionally malnourished for several weeks). Stone particularly noted that he had been unable to determine whether she had been competent at the time the dehydration commenced.

With Stone's report in hand, Judge Tolton ruled that the dehydration should be completed. Before an appalled Stone could appeal, Marjorie died on April 6, 1995.

Similarly, a woman, who was declared brain dead by the doctors, went on to live, not only for another 200 days, she even gave birth to healthy children thereafter. ${ }^{61}$ In the same vein, a young boy, whose doctor said was brain dead, lived on, for over 14 years on a ventilator with adequate basic nursing support. ${ }^{62}$

In the United States of America, one Terry Wallis, had a car accident in 1984, and had been in coma since then. He however, began to breathe again after 19 years. ${ }^{63}$ In 2005 , Salvatore Crisafulli, an Italian, woke up from coma after doctors declared her to be "nearly dead." Salvatore had been in coma for 2 years as a result of an auto accident. $^{64}$

Furthermore, a railway worker in Poland was said to have left doctors and family members wandering in 2007, when he breathes life again after 19 years. Due to the incident, one of the treating doctors admitted that ever since he has been practising the profession for the past ten years in the same hospital, he has never witness a person recover from coma as Rae. On her part, like Raleane, Rae thanked God for saving her. It is important to state here that from the statement of Rae, it can be inferred that only God alone, and not any doctor or patient can determine when and how a person dies. ${ }^{65}$

61 Ibid; see also "A Case That Was Even More Tragic than Terri Schiavo Discussion on Topix," accessed April 20, 2016, http:/www.topix.com/ forum/news/terri-schiavo/TFJR8R58B1ITF3K08.

62 Roberto De Mattei, Finis Vitae. Is Brain Death Still Life? Atti Del Convegno (Città Del Vaticano, 3-4 Febbraio 2005) (Rubbettino Editore, 2006).

63 Byrne, "The Demise of 'Brain Death."

64 Ibid.

65 The Qur'an (al- 'Imrān: 145). 
In addition, there is also the case of one Kate Adamson who has been in a permanent vegetative state for 70 days after suffering a stroke. After the removal of her feeding tube, she began to die slowly for 8 days. Suddenly, she began to respond on her own, and the feeding tube was re-inserted by the doctors. Consequently, she regained full consciousness. According to Kate, throughout the period of her coma, she hears and sees all that goes on around her, but lacked the will to communicate. For being alive again, Kate gave thanks to God and wrote a book, titled, "Kate's Journey: triumph over adversity.",66

Also Raleane Kupfer Schmidts, was in mid-January 2008, diagnosed as suffering from a massive cerebral haemorrhage. ${ }^{67}$ On the basis of the conclusion of the doctor that she is "brain dead," her feeding tube was removed. But, while every member of her family was waiting to receive the news of her death, she suddenly began to move her hands, and even answered calls. In her words, Raleana, said, she could not remember anything throughout the period of her coma. ${ }^{68}$ She however concluded that God was her saviour. ${ }^{69}$

It can be inferred from the entire incident above, that when a patient is on life support, as a result of brain injury, there should be some time out, i.e. in the form of patience, on the part of the doctors and relatives, before concluding that such patient is dead. This, as stated earlier has been confirmed by a 2010 research. ${ }^{70}$

However, with regards to Islamic law, as shall be seen below, there can never be a removal of life support on the basis of brain death, unless, the heart or respiration of such patients has stopped working. ${ }^{71}$ In other words, death in Islam must include the whole part of the human body and not part of it (Al- yaqeen La yazulu bi al

66 "She Recovered From A Persistent Vegetative State," accessed April 20, 2016, http://www.rense.com/general44/vege.htm.

67 "Cerebral Hemorrhage - Symptoms, Causes, Treatments - Healthgrades.com," accessed April 20, 2016, http://www.healthgrades.com/conditions/cerebralhemorrhage. Cerebral haemorrhage is uncontrolled bleeding in the brain. It can occur from an injury or as a result of a leaky or burst blood vessel. This can happen when a blood vessel gets weakened enough that its wall can no longer withstand the pressure of the blood flowing through it.

Ibid.

Ibid.

Monti et al., "Willful Modulation of Brain Activity in Disorders of Consciousness."

71 "Brain Death in Islamic Jurisprudence - Dr. Abdulaziz Sachedina," accessed April 20, 2016, http://islamicstudies.islammessage.com/ResearchPaper.aspx? aid $=568$. 
shakk). ${ }^{72}$ This position is ably supported by the conventional medical definition of death. According to the definition, "death can only occur, if there is permanent cessation of all vital bodily functions.",73

\title{
THE RESPONSE OF ISLAMIC LAW TO THE BRAIN DEATH CRITERIA
}

Islam places utmost importance on the sanctity of life of mankind, hence it is one of its cardinal principles. ${ }^{74}$ Islam therefore forbids a Muslim from taking the life of another person. It is important to state however, that under certain circumstances, Islam allows the taking of life of a fellow mankind only with just cause. ${ }^{75}$ The circumstances, as shall be seen later, do not include the withdrawal of a patient's life support system, because he or she is brain dead.

Thus, as a way of showing the importance which Allah attaches to human life, the holy Qur'an puts it succinctly thus,

\begin{abstract}
...And do not kill anyone whose killing Allah has forbidden, except for a just cause. And whoever is killed wrongfully (Mazluman Intentionally with hostility and oppression and not by mistake), We have given his heir the authority [to demand Qisas, - Law of Equality in punishment- or to forgive, or to take Diya (blood money]. But let him not exceed limits in the matter of taking life (i.e. he should not kill except the killer). Verily, he is helped (by the Islamic law). ${ }^{76}$
\end{abstract}

According to the views of the majority of the schools of law in Islam, a person can be held responsible for the death of another; even where he did not actively kill the victim. ${ }^{77}$ In arriving at this conclusion, Imam Maliki, Shafi'i and Ahmad Bin Hanbali, made certain

72 Ibid.

73 "Definition of Death," accessed April 20, 2016, http://www.medterms.com/ script/main/art.asp?articlekey $=33438$.

74 Ibid.

75 Al- Muslim, Sahih Al- Muslim, 5: 107-108; see also Al - Bukhari, Sahih AlBukhari, 8: 148.

76 The Qur'an (al- Isra': 33).

77 Al-Sharh-ul-Kabeer, lil Durdeer, 4 (n.d): 215; see also Al Ramli, Shams al Din Muhammad b. Abi al 'Abbas Ahmad b. Hamzah b. Shihab al Din. Nihat-ulMuhtaj, Ila Sharih al-Minhaj vii (Cairo, Mustafa al-Babi, 1968); Al-Shirbini, Muhammad al Khatib. Mughni al-Muhtaj ix (Cairo: Mustafa al- Babi, 1958) 
illustrations. ${ }^{78}$ They said that if a person is imprisoned in a building without being fed with food and drinks, and death ensues, then, the person who detained the victim shall be held responsible for the latter's death. ${ }^{79}$ These scholars premised their argument on the basis that water and food is essential to the survival of mankind. Thus, the denial of these basic amenities to the victim caused his death. In supporting the views of the majority, Imam Muhammad and Yusuf are of the opinion that the accused is guilty of intentional homicide. ${ }^{80}$ This, according to them, is because it is impracticable for human beings to survive without basic needs like food and water. ${ }^{81}$ The implication of the above illustration is that, although, the accused did not actively kill the victim, he (accused) did not give him food and drink, which is the consequence of his death. The conclusion is that he (accused) is indirectly the killer, because of his (accused) refusal to give the victim food and drink.

However, Imam Abu Hanifah disagreed with the three scholars. According to him, the accused did not do anything to cause the death of the victim; rather, it is hunger, resulting from lack of food and drink, which caused the victim's death. ${ }^{82}$ It would seem, with respect, that Imam Abu Hanifah did not take note of the cause (sabab) of the hunger. ${ }^{83}$ The term, 'food and drink,' has been employed here because, the conventional withdrawal of patient's treatment on the basis of the Harvard's brain death criteria has always been followed by the denial of food and drink to such patients. The reason is that, in their opinion (advocates of the brain death criteria), the patient's quality of life has depreciated and so if he or she is denied food and drink, his or her death would come faster. The pertinent question here would be if really brain death is death, why deny such patient food and drink, which are basic necessities of life?

Ibid.

79 Al Kassani, Badā 'i Al-Sanā ’ $i$ F̄̄ Tarțīb Al-Shar '̄o vii (Cairo: 1910) ; see also Ibn Nujaim, Zain al 'Aabidin b. Ibrahim, Al Baḥr-ul-Rāiq Shar Kanz Al Daqaiq viii (Pakistan: Al Mutba'ah Al 'Arabiyyah, n.d)

80 See Al-Sharh-ul-Kabīr, lil Durdeer, n. 77.

81 Ibid.

82 Ibid.

83 It is strongly believed, with respect to Imam Abu Hanifa, that if he had addressed his minds to the initiator of the denial of food and drink in the illustration given, his opinion would have been otherwise. The reason is that the deceased was detained by somebody. Death ensued from the refusal of that person to provide the deceased with basic necessities of life, the accused indirectly can be said to have caused the deceased death. 
However, some contemporary scholars, such as Qaradawi and Muzammil, amongst others, seem to allow withdrawal of life support machines on the basis of Imam Abu Hanafi's view. ${ }^{84}$ This is because these scholars are of the view that since the patient is in an irreversible coma, disconnecting such patient from the machine is in order, although, Qaradawi stated further that, the patient's food and hydration should not be stopped. ${ }^{85}$ Thus, if reliance is placed on the views of Imam Hanafi, such act is not murder because the act is not direct. $^{86}$

In the same vein, the council of Islamic Jurisprudence (Majma' al- Fiqh al- Islami) at a meeting held in Amman, Jordan on the $16^{\text {th }}$ day of October, 1986, held that,

It will be permissible to switch off the life support with total and irreversible loss of function of the whole (not part) of the brain of a patient. [Further they said] that this will be legal if three treating doctors have agreed that irreversible cessation of the brain function has occurred, [This will be the case] even if the basic functions of the heart and lungs are externally supported by life support system. $^{87}$

The above statement affirms, once again, a thinking that is in line with the controversial Harvard brain death criteria. ${ }^{88}$ This, with respect, is not the Islamic law position because it means the person, in the above state, is still very much alive. Thus, any removal at this

84 Yusuf AL-Qaradawi, "Fatawa Mu'asirah, Dar al-Wafa il al-Tiba'ah wa alNashr wa al-Tawzi," ii (Egypt, 1993) ; see also "Yusuf AL- Qaradawi," "Questions \& Answer about Euthanasia in Islam," accessed April 20, 2016,http://www.islamonline:net/servlet/satellite?cid=1119503544774 \&page name/islamonline- Ask_scholar/fatwa/fatwa E Ask The scholar.

Irreversible coma has been the yardstick for determining the removal of a patient's life support. This irreversible coma, which has been found to be faulty, was derived from the Harvard medical school.

86 The act of removal here is termed a negative one. That is, the doctor did not take any active part in the death of the patient after the removal of the machine. But the majority of the scholars said that, the doctor or whosoever removed the machine will be liable. This is because; the removal was the actual cause of the death of the patient.

87 "Council of Islamic Jurisprudence" (Majma' al- Fiqh al- Islami)" (Meeting of Council of Islamic Jurisprudence held at Amman, Jordan, October 16, 1986. It can equally be viewed on accessed April 20, 2016, http://www.islamusa.com/e113.htm Ibid. 
stage will be tantamount to murder. This latter position is supported by another Islamic scholar, Dr Maher M. Hathout who is the spokesman for the Islamic centre of Southern California. ${ }^{89}$

According to the cardiologist, as long as the patient is alive and on a support machine, Islam forbids such removal. He stated further that, if however, the patient is no longer alive, i.e. when the patient's brain stops functioning, any removal at this stage will be alright. The above position, taking by the learned scholar has again fallen in line with the conventional brain death criteria. ${ }^{90}$ This is because he adopts the word, 'stoppage of brain function,' as a basis for withdrawal of life support, thereby leaning towards the Harvard definition of brain death. ${ }^{91}$ This can therefore be said to be the reason why the learned physician is quick to point out later that religious guidelines by Muslim scholars are not always adhered to in practice by the public. This is because in reality some family members are emotionally attached to their loved ones such that they will not subscribe to the removal of their life support machines. ${ }^{92}$

However, on what amounts to legal death, the council said that a legal death will only occur if, after switching off the life support, all the vital or necessary organ of the body ceases to function. It can be inferred from the above definition that, if life support machine of a patient is switched off, but vital organs are still functioning, there is no death in Islam. Thus, the council's definition of legal death, as the basis for the removal of organs or switching off of life support is therefore faulty. This is because they are of the opinion that, life support can be switched off and organ removed even if the heart is still working.

\section{Al-Sharh-ul-Kabīr, lil Durdīr. \\ Council of Islamic Jurisprudence.}

Al-Sharh-ul-Kabīr, lil Durdīr, n. 77, provides a comprehensive explanation of the principle underlying withdrawal and withholding of a patient's treatment in Islam. It must be added that the Harvard's brain death criteria, implies that life support can be removed even if certain organ of the patient is still functioning. In Islam, and to opponents of euthanasia and assisted suicide, such act amounts to active killing.

92 This is exactly what Islam is preaching. That is, in time of adversity, we should show love to our brethrens, families and well-wishers. This is also the views of those opposed to legalization of euthanasia and or assisted suicide, which is that, terminally ill people do not need to be hastened to death. Rather, they should be cared for; they should be assured that they are not burdens, until natural death comes from God. 
It is important to emphasize here that no matter how beautiful, reasonable or sound a scholar's view may be, that view can never stand the test of time in the face of a clear text of the glorious Qur'an, being the chief or primary source of law in Islam. This position has been supported by a Qadi of the Shari'ah court of appeal who said that if the views expressed by any scholar have basis in either the holy Qur'an or Sunnah of Prophet Muhammad (s.a.w), that view becomes law. ${ }^{93} \mathrm{He}$ however said, that, if views of such a scholar are contrary to a clear text of the Qur'an or Sunnah of Prophet Muhammad (hadith), that view will therefore not be a law to be followed by Muslims. ${ }^{94}$

Thus, it is safe to conclude that the above views (Imam Maliki, Shafi'i and Hanbali), provides an answer to the position of Islam with regards to withdrawal and or withholding of treatment from patients on life support machines. ${ }^{95}$ It will therefore be correct to say that under Islamic law, disconnection of patients' life support machines can only take place if their (patients) sustenance does not depend on the machine. In other words, if the disconnection of a life support machine will immediately leads to the death of the patient, it should not be carried out. This is in line with the views of majority of the scholars. ${ }^{96}$ A removal of such machines is tantamount to intentional or wilful murder. That is, even though; the actor did not actively kill the patient, he or she has indirectly caused the patient's death by disconnecting the support machine. What is therefore suggested in cases where the patient is in an irreversible coma is to disconnect the machine, without stopping food and hydration. The wisdom here is that, the patient should continually be fed until death comes naturally. This position has been further strengthened by recent researches which revealed that patients described as being in irreversible coma, have survived such coma. So, denying such patients food and

\footnotetext{
93 Mohammed O. Salihu, Interview by Bashir A. Omipidan, January 2, 2009.

94 Ibid

95 It is important to also emphasise that some contemporary scholars like Kasule Omar, Kiaresh and Amaresh, toed the line of the majority views of the schools of Islamic jurisprudence on the issue. See Kasule H. Omar, "Euthanasia: EthicsLegal Issues," April accessed 20, 2016, http://www.Islamonline.net/english/news/2002-11/26/article61.shtml; see also Kiarash Aramesh and Heydar Shadi, "Euthanasia: An Islamic Ethical Perspective," Iran J Allergy Asthma Immunol 6, no. 5 (2007): 35-38. 
hydration will be tantamount to hastening their death. ${ }^{97}$ This position is supported by the Muslim health care givers at the first International conference on Islamic Medicine held in Kuwait in 1981. Part of the communiqué released at the conference is contained in Article 61 and 62 of the Islamic code of medical ethics. Article 61) provides: "That in all cases of voluntary euthanasia, persistent vegetative state and killing of newly born infants with deformities that may or may not threaten lives, killing or hastening of deaths is illegal." Article 62 on the other hand, represents an appeal to Muslim medical personnel. The article provides that, "the treatment of a patient can be terminated if a team of medical expert or medical committee involved in the management of such patient are satisfied that the continuation of treatment would be futile or useless." They concluded by saying that the, "treatment of patients whose condition has been confirmed to be hopeless by the medical committee should not be commenced." 98 That is, once it is concluded from prognosis and diagnosis that the patient cannot survive the illness, doctors should not proceed with such treatment.

The above position is supported by the story of Caliph 'Umar (R.T.A) after sustaining an injury. ${ }^{99}$ While receiving treatment, his doctor gave him milk and it returned through his stomach. ${ }^{100}$ At this juncture, the doctor concluded that Caliph 'Umar was not going to

97 It would be recalled that Terri Schiavo and Eluana Englaro who were both on artificial support machine as a result of a brain injury, had their feeding tubes removed based on an application of their guardian ad - litem. The contentions of the guardian were that they were in an irreversible coma, they both died as a result. It is the same brain death criteria that formed the basis of the court's decision in the two cases that stretched both the American and Italian judiciary to the limit.

Being Part of the code of conduct drawn and called, "the Islamic Code of Medical Ethics," at the International Conference on Islamic Medicine (Kuwait: Islamic Organization of Medical Science, 1981)

99 Abdul Qadir 'Oudah Shaheed, Criminal Law of Islam, vol. 4 (Adam Publishers, 2010); see also Al Baḥr-ul-Rāiq, vol. 8, 295; Nihāyat-ul-Muhtāj, vol. 17, 250251; Muwahib-ul-Jaleel-lil-Khattab, (n.d) 6: 244; Al Sharh-ul-Kabīr lil Durdir, 9: 238.

Ibid. 
survive the ailment. ${ }^{101} \mathrm{He}$ therefore advised 'Umar, to make his dying declaration as a parting word of advice to the ummah. ${ }^{102}$ Consequently, Caliph 'Umar set up a shura (consultative assembly). ${ }^{103}$ The essence is to elect the next caliph, since his doctor is sure that he can no longer recover from the injury. All the advices and agreement reached prior to Umar's death became acceptable to his followers. ${ }^{104}$ The significance of the above illustration is to show that, once a person is still alive, no matter his or her illness, he or she should never be killed. Thus, to withdraw the support machine of a person whose sustenance depends on such a machine amounts to an intentional murder. This represents the views of opponents of the brain death criteria and majority of scholars in Islam. This is so because they (opponents of brain death criteria and majority of scholars in Islam) views, food and hydration as part of the treatment that keeps life going.

Hence, the removal of such basic necessities of life is tantamount to tacitly killing the patient. ${ }^{105}$ It therefore follows that, for death to be the basis for disconnecting a patient's life support device there must be cardiac respiratory failure. ${ }^{106}$ Cardiac respiratory failure means that every necessary organ like the lung, heart amongst others must stop working. ${ }^{107}$

101 The above statement can be likened to the views of the Islamic medical personnel, who are of the view that if the prognosis of a patient attests to the fact that the continuation of his or treatment will be futile. life sunnort in such circumstances may be withdrawn.

above, food and hydration were still on. That is why he was able to form a shurah, which decided his successor. Nihāyat-ul-Muḥtāj.

Ibid.

The subsequent adherence to all his advices, affirms the fact that he is still respected as a leader even at that state. It shows further that, until functional part of a person's body stops working, there should be no conclusion that the person is dead.

105 Kamisar Yale, "The Reasons So Many People Support Physician-Assisted Suicide-And Why These Reasons Are Not Convincing," in Ethics at the End of Life, ed. Ralph Baergen (Wadsworth Publishing Company, 2001), 175-84.

106 Ibid.

107 Ibid., 182-184. 


\section{CONCLUSION}

It is important to note that the basis for advocating for the withdrawal of patient's life support device lies upon the brain death criteria. Even the Muslim scholars that are in support of withdrawal equally based it on the same criteria. ${ }^{108}$ This criterion, as explained earlier on has been proved to be questionable and should no longer be the basis for determining the death of a person in an irreversible coma or permanent vegetative state. Rather, the total cessation of the patient's bodily function should be the basis for determining death. Apart from the above, it is also important that human beings fear Allah, as the care of the patient, not their death should be uppermost in their minds. On this Allah says,

Your Lord knows best what is in your inner selves. If you are righteous, then, verily, He is Ever Most Forgiving to those who turn to Him again and again in obedience, and in repentance. ${ }^{109}$

Patients are also enjoined to be patient in adversity and to rely on Allah instead of taking steps to hasten their own death, as whoever does that has not only disobey Allah, but shall face punishment in the hereafter. The holy Qur'an on this point says,

My son! Aqim-Al-Salat [perform As-Salat], enjoin [on people] Al- Ma' ruf-(Islamic Monotheism and all that is good), and forbid (people) from Al-Munkar [i.e. disbelief in the Oneness of Allah, polytheism of all kinds and all that is evil and bad], and bear with patience whatever befalls you. Verily, these are some of the important commandments [ordered by Allah with no exemption]. ${ }^{110}$

This Qur'anic verse is supported by a hadith of the holy prophet Muhammad, which is narrated by Anas. ${ }^{111}$ According to the hadith, Allah's messenger (s.a.w), is reported to have said,

None of you should long for death because of a calamity that had befallen him; and if he cannot, but long for death, then he should say, O Allah! Let me live as long as life is better for me, and take my life if death is better for me. ${ }^{112}$

\footnotetext{
108 "Brain Death in Islamic Jurisprudence - Dr. Abdulaziz Sachedina."

109 The Qur'an (al- 'Imran: 145).

110 The Qur'an (Qur'an, Luqman: 17); (Qur'an, az- Zuma: 39).

111 Sahih Al- Bukhari, 8: 362.

112 Ibid; see also The Qur'an (Al-Hijr: 99).
} 
Health care personnel, families and relations of sick persons are also to show affection and love to their sick relatives even when the ailment is terminal in nature until Allah finally takes his or her soul. Doing this, translates into an assurance to such patient that he or she is not forgotten. Besides withdrawal of treatment or life support machine should only be resorted to as a last option, where the continuation of the patient's treatment will be futile. The conclusion of a futile treatment should, as the Muslim medical ethics conference said, be based on sound medical decision. In doing this, the patient's relation must be carried along, while the medical team should as much as possible put the fear of Allah (God) at the back of their mind, in taking such decision. This is because; the well-being of the patient, rather than his or her hastened death should be of paramount importance to the medical team. This work therefore concludes that Harvard's brain death criteria should never be the basis for declaring a person dead thereby necessitating the withdrawal of such person's life support machine. Thus a brain death person can only be declared dead if all functional bodily organs cease to work. 